\title{
THE INFLUENCE OF CO-WORKER INCIVILITY TOWARDS DEVIANT BEHAVIOUR: A QUANTITATIVE STUDY OF CASUAL DINING RESTAURANTS FRONTLINE EMPLOYEES IN THE KLANG VALLEY, MALAYSIA
}

\author{
Narehan Hassan ${ }^{1}$, Tasnimul Islam ${ }^{2}$, Rozilah Abdul Aziz ${ }^{3}$ \\ 1,2,3 Universiti Teknologi Mara, Puncak Alam, Selangor, Malaysia.
}

\begin{abstract}
The past decade has seen a growing number of casual dining restaurants in Malaysia. This trend of consumption is due to modern lifestyle, socio-demographic, and social media influence. Nevertheless, restaurants struggle to maintain a productive work environment and report to have association with incivility and deviant behaviour which in long run create destruction. The aim of this paper is to examine the influence of co-worker incivility towards employees performing deviant behaviour with the moderating role of emotional labour. Total of 120 questionnaires were distributed to the frontline employees of casual restaurants in the Klang Valley. The result pointed out that there was a significant positive correlation between co-worker incivility and deviant behaviour with a moderating effect of emotional labour.
\end{abstract}

Keywords: Deviant behaviour, Co-worker incivility, Casual dining restaurants, Klang Valley.

\section{Introduction}

Customer In the last few decades, organisations have had a single focus on "profit", which was based solely on the stock prices. However, the outliers on the other side of the spectrum have been ignored, which are namely the "employees", despite their established value as the most important assets of an organisation. According to Rasool and Maqbool, (2019) employees can be categorised as "stars", who substantially increase organisational output and "toxic workers", who are simply unsuitable for the organisation. According to Choi and $\mathrm{Ha}$, (2018) $80 \%$ of the issues and concerns regarding employees' productivity are related to the type of work environment in which they operationalise their assigned tasks. Stress may be an inevitable aspect of people's life. It is becoming increasingly difficult to ignore stressors at the workplace. In recent years, one type of work stressor that has received a great deal of research attention is workplace incivility (Karatepe \& Kim, 2019). Results indicated that targets of incivility tended to demotivate wellbeing, job satisfaction, work effort, and a higher work turnover (Loh \& Loi 2018). Moreover, when employees frequently faced such noxious aspects of the work environment, they become less motivated and unable to focus on their job (Daly \& Carey, 2018).

In the line of hectic restaurant environment, factors such as rude customers, co-workers or an angry supervisor, may be a fact of life for some employees (Olson \& Sinsky, 2019). Study conducted by Demsky and Fritz, (2019) showed significant rise of incivility in organisation. According to Abubakar and Megeirhi (2018), incivility of co-workers is commonly observed in an organisation which showed indication of rapid growth. The time when employees are trying to adjust with the incivility, they adopt emotional labour. Emotional labour is termed as per Hochschild (1983) that emotional labour involves the induction or suppression of feeling in order to sustain an outward appearance that produces in others a sense of being cared for in a convivial, safe place (Delgado \& Roche, 2020).

Emotional labour is particularly typified by three characteristics: face-to-face or voice contact with the public; it requires the workers to produce an emotional state in another; it allows the employers through training and supervision to regulate a degree of control over the emotional activities of workers (Winter \& Morrison, 2019). The term 'emotional labour' highlights the similarities as well as differences of emotional and physical labour. Emotional labour requires an individualised but trained response that assists in the management of emotions in the everyday working life (Lavee \& Strier, 2018).

On the other hand, deviant work behaviour (DWB) is termed as a voluntary act that aims to harm individuals or the organisation. Study conducted by Javed and Fatima, (2019) had shown that DWB causes devastation effects for any organisation and leads to workplace aggression, interpersonal conflict, discouragement, and mischief. Furthermore, DWB creates misfortune towards organisational purpose, reduces the organisation's effectiveness, harms equity perceptiveness, and negatively affects the organisation's social structure (Haider \& Nisar, 2018). Deviant work behaviours are not only aimed at organisational norms but also intend to harm social norms in the workplace (Stefano \& Scrima, 2019). From a study conducted by Lin and Yu, (2020), alleged deviant behaviour 
was increasing in between organisation employees and measures must be taken to control and find the cause of deviant behaviour. On the same note, emotional labour was found to be adopted by service personal to alter their felling in case uncivil situation (Xu \& Cao, 2020). Organisational researchers need to better understand what constitutes uncivil supervisor and co-worker behaviours and how to reduce their occurrences in workplaces (Roberts \& David, 2020). Hence, this paper attempts to address the influence of co-worker incivility on frontline employee deviance with the moderating role of emotional labour among casual dining restaurant employees located in the Klang Valley.

\section{PROBLEM STATEMENT}

The workplace environment can be classified into two major categories: collaborative workplace environment and toxic workplace environment (Anjum \& Ming, 2018). The collaborative workplace environment yields a sense of happiness, joy, harmony, kindness, politeness, cooperation, and facilitation at the workplace (Gualtieri \& Rauch, 2018). The workplace is toxic when individuals in power are greedy and narcissistic and/or use unfair means to bully, harass, threat, and humiliate others (Wolf \& Perhats, 2018). The toxic workplace can cause anxiety, stress, depression, health problems, absenteeism, job burnout, counterproductive work behaviour, and ultimately degrade productivity. Loh and Loi, (2018) had found that incivility is now at all-time high in different service sectors and huge number of employees are being a victim of incivility. According to Roter, (2018) restaurants employees are one of the worst victims of incivility caused by superiors. From 2000 to 2016, the U.S. suicide rate among service sector workers aged (16-64 years) adults increased $34 \%$ from 12.9 per 100,000 population to 17.3 (Peterson \& Stone, 2018). A study conducted by Johnson and Hall, (2018) stated that the number of suicide cases among service sectors employees is increasing and steps must be taken to protect their lives. Restaurant employees are reported to perform deviant act which financially destroy the company's future growth (Nugroho \& Oktavio, 2019). Limited number of studies have focused on restaurant employees' moral health and development (Jin \& Kim, 2020).

\section{RESEARCH OBJECTIVES}

RO1: To identify the relationship between co-worker incivility and deviant behaviour.

RO2: To investigate the moderating role of emotional labour towards the relationship between co-worker incivility and deviant behaviour.

\section{RESEARCH QUESTIONS}

RQ1: Is there any relationship between co-worker incivility and employee deviant behaviour? RQ2: What are the moderating roles of emotional labour towards the relationship between co-worker incivility and employee deviant behaviour?

\section{LITERATURE REVIEW}

Frontline employees are essential position in service-based company as they constantly have interaction with customers which gives them a strong sense of what consumers desire and relish about the firm's core service (Choi \& Mohammad, 2019). As a result, frontline employees are imperative company asset and good source of ideas for product improvements and innovations. In the food service industry, the frontline role in service delivery process determines the success of service and design of marketing programmes (Wirtz \& Patterson, 2018). Casual dining is a unique sector of the food service industry which serves moderately priced food, averaging from RM10 to RM40 for dinner per diner, in an informal and relaxed atmosphere with a full-service wait staff (Yusof \& Jusoh, 2020). Casual dining restaurants compete on several factors such as variety, atmosphere, and food quality (Saad \& AbuKhalifeh, 2020). According to Hussein, (2018) food quality influences customers for the selection of a casual dining restaurant, followed by cleanliness, service, value, menu variety, reputation, atmosphere, and convenience. Furthermore, Anthonia and Olalekan, (2018) in their findings are also in-line where top influences on people's choices are food quality, taste, speed of service, cleanliness, and value.

Past researches had indeed demonstrated that positive social interactions with colleagues promote positive emotions and good work environment (Nelson \& Klumparendt, 2018). Meanwhile, adverse events such as facing abusive supervisors can induce negative emotions in subordinates (Eissa \& Lester, 2019). When employees frequently face such noxious aspects of the work environment, they become less motivated and conduct deviant behaviour on their job tasks (Schnall \& Dobson, 2018). Morgan and Perry, (2018) in their study suggested deviance as the behaviour that is toxic to the working environment and consequently leads to workplace aggression. Furthermore, Tuzun and Kalemci, (2018) also agreed that DWB is the type of behaviour that demoralises the organisation teammates and negatively influences shared organisational norms and expectations as well as basic social values, habits, and production. In pragmatic effect, when DWB takes place and becomes a norm in an organisation, it constitutes toward financial organisational problem (Haider \& Nisar, 2018). Therefore, deviant behaviour creates misfortune towards organisational purpose, reduces the organisation's effectiveness, harms equity perceptiveness, and negatively affects the organisation both financially and non-financially (Shoaib \& Baruch, 2019).

On the other hand, co-worker incivility is characterised by attitudes and behaviours aimed at disturbing and teasing fellow workers, 
which sparks negative and unhealthy competition where the sole motive is to tear each other down and has a total spiralling effect on the environment of the workplace (Viotti \& Converso, 2018). Co-worker incivility causes physical and mental exhaustion and has a downward effect on the performance and team spirit of employees (Geldart \& Langlois, 2018). As a result of co-worker incivility, an employee loses its confidence and teamwork on his colleagues and co-workers, eventually the employee resists to share ideas, opinions, experience, and skill with them (Zhu \& Lam, 2019). Co-worker incivility also includes negative and hurtful comments, leg-pulling, gossips, weird staring, and its prompts negative emotions among employees (Yuniasanti \& Abas, 2019). Moreover, co-worker incivility is also found to have a strong link with adverse outcomes concerning emotional stability, exhaustion, withdrawal behaviours, and worsened psychological health (Portoghese \& Leiter, 2018). According to Anglim and Sojo (2019), "Co-worker incivility can have a significant adverse effect on organisational outcomes through burnout, self-reported withdrawal behaviour, and psychological health problems" (p.6). Cho and Bonn, (2016) found that experiencing incivility is related to increasing adverse feelings and decreased work effort by a co-worker. After having an instance review of literature, the researcher constructed the following hypothesis,

\section{$\mathrm{H}_{1}$ : Co-worker incivility has significant relationship with employee's deviant behaviour.}

The moderating role of emotional labour between coworker incivility and deviant behaviour

At the edge of 21 st century, incivility has become a costly problem which has created a damaging effect on both organisation and other entities in the workplace (Sguera \& Bagozzi, 2016). According to Aljawarneh and Atan (2018), "From the employees' standpoint, frequent workplace incivility appears to reduce their sense of belonging towards the organisation, which includes contributing to psychological distress, increasing the level of emotional-exhaustion, undermining their efforts, increasing the time required on the job, reducing job satisfaction, and also fostering an intent to leave the occupation" (p.16).

Moreover, workplace incivility increases the cost of recruitment, training, and the retention of mistreated employees (Hur \& Moon, 2019). According to Bennett and Marasi (2018), "Incivility potentially undermines the status and profitability of a corporation because customers can become less enthusiastic about purchasing products from a company whose employees are perceived as impolite" (p.22). A major sample collected randomly of American employees found that verbal abuse from customers towards employees occurred more frequently than verbal mistreatment from supervisors and co-workers towards employees (Mendonca \& Cruz, 2018). Previously, there was meta-analytical evidence to suggest that interpersonal mistreatments relate to a variety of undesirable reactions including dissatisfaction with work performance, depression, a decrease in self-esteem, and anxiety (Zheng \& Dijke, 2020).

Thus, interpersonal mistreatments can be antecedents to negative emotional responses in different people (Bendersky \& Brockner, 2020). Similarly, experiencing unfair treatments from colleagues, such as being treated in rude and condescending manners, is damaging to the targeted individuals' emotions (Garcia \& Restubog, 2019). Furthermore, job stress as a condition will force a person to deviate from normal working due to changes in psychological state of mind. Such person is automatically forced to deviate from normal functioning unless one knows how to manipulate emotion (Wu \& Li, 2018). Miranda and Godwin, (2018) also treated emotional labour as a self-protection mechanism for employees in any unsocial work environment. Moreover, Lefebvre and Randerson, (2020) treated different forms of emotional labour as different coping strategies to deal with stress. Based on the literature review, the researcher has developed the following hypothesis:

\section{$\mathrm{H}_{2}$ : Emotional labour has moderating role between co- worker Incivility and employee deviant behaviour. UNDERPINNING THEORY}

General Strain Theory (GST) argues that strains or stressors strongly trigger negative emotions like anger and frustration (Barbieri \& Clipper, 2019). Negative emotions create an adverse pressure for remedial action by a victim (Y1ldiz \& Solakoglu, 2019). Crime is a notion of escapism to reduce the strain (e.g., stealing the money for your desire) seeking revenge or improving pessimistic personal views associated with feelings (e.g., through illicit drug use), (Liu \& Miller, 2019). According to (Golladay and Holtfreter, 2020), "GST strengthens by comparing with previous theories by identifying several new categories of strain, including the loss of positive emotion (e.g., loss of a romantic partner, death of a friend), the presentation of negative stimuli (e.g., physical assaults and verbal insults) and new categories of goal blockage (e.g., the failure to achieve justice goals)" (p.8). Kim and Siennick, (2018) found out high-magnitude strains attached to an individual's low self-control had created an unjust nature whereby it caused the individual to adopt for retaliation in response. Thus, negative emotions create pressure for corrective action or deviant behaviour in ways that some individuals respond. GST focuses on factors of strain such as the adverse treatment by others, work overload, interpersonal relationships, role conflict, role ambiguity, inability to achieve goals, and loss of valued possessions (Agnew \& Brezina, 2019).

Moreover, Agnew (2019) defined strain as "negative or aversive relations with others" which has three types: "strain as the actual or anticipated failure to achieve positively valued goals, strain as the actual or anticipated removal of positively valued stimuli, and strain as the actual or anticipated presentation of negative stimuli" (p. 59). GST posits that strain generates negative 
emotions that provide motivation for deviance as a coping strategy because such emotional forces create pressure for corrective action. Thus, because strain's unmitigated effects are open to alternative theoretical explanations (Agnew, 2019), the empirical validity of GST depends on the extent to which negative emotions mediate the effects of strain on deviance and crime. Moreover, GST can also be justified to be used for measuring any deviance related activity (Peck \& Childs, 2018).

Furthermore, according to the meta-analysis conducted by Nguyen and Stinglhamber (2020), evidence suggests that interpersonal mistreatments relate to a variety of undesirable affective reactions including dissatisfaction with work, depression, a decrease in self-esteem, and anxiety. Thus, interpersonal mistreatments can be antecedents to negative emotional responses in individuals. Similarly, experiencing incivility from colleagues, such as being treated in rude or condescending manners is damaging to the targeted individuals' emotional state (Taylor \& Hardin, 2018). According to Aanonsen (2020), "If spiralling behaviour is left unchecked, targets may retaliate intentionally, contributing to the spiral of increasingly intense, aggressive behaviour that can negatively affect a wide range of worker attitudes and practices, including worker engagement" (p.6).

\section{RESEARCH FRAMEWORK}

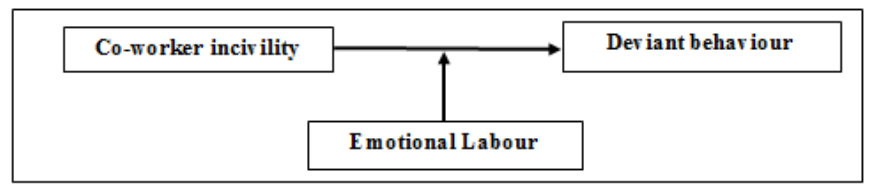

Figure 1: Research framework
(Bennett \& Robinson, 2000), and for emotional labour (Brotheridge \& Lee, 2003) were distributed personally to the respondents. Several sections were considered for the questionnaires based on the objectives of the study. Non probability Purposive sampling was used for gathering research data. Respondents were restricted to frontline employees working in selected casual dining outlets located in IOI Putra Jaya shopping mall. Respondents were asked to rate their level of agreement for each item on a 5-points Likert scale ranging from $1=$ Strongly disagree to $5=$ Strongly agree.

In this study, a total of 128 questionnaires were distributed and 107 questionnaires were finally obtained for further analysis. The data were recorded and analysed using (SPSS) version 25. Results and discussion are available in the next section.

Overall, the percentage of gender between male and female where female consisted of $46.7 \%$, while male comprised of $53.3 \%$ from the total respondents of the study. Main stream of respondents were aged between 16 to 25 years old $(73.8 \%)$ followed by 26 to 30 years old $(26.2 \%)$. It clearly shows that this study contained a larger number of generation $\mathrm{Y}$ population.

In the demographic section as well, the employees were asked on how many hours they worked in a day. For that, a slightly more than half of the employees which accounted for $61.7 \%$ had worked for 5 to 10 hours, $38.3 \%$ worked for 11 to 15 hours. Also, results had found that for work experience it shows $72.0 \%$ of having work experience of 7 months to 1 year, followed by $17.8 \%$ having work experience 7 months to 1 year followed by $10.3 \%$ with work experience of 2 to 3 years.

\section{RESEARCH METHODOLOGY}

Quantitative method was used and adopted questionnaires for co-worker incivility (Cortina, 2001), deviant behaviour

Table 1.1: Demographic of Respondents

\begin{tabular}{|l|l|l|l|}
\hline Variables & Categories & Frequencies & Percentage \\
\hline Age of respondent & $\mathbf{1 6}$ to 25 years old & $\mathbf{7 9}$ & $\mathbf{7 3 . 8}$ \\
& 26 to 30 years old & 28 & 26.2 \\
\hline Gender of respondent & Male & $\mathbf{5 7}$ & $\mathbf{5 3 . 3}$ \\
& Female & 50 & 46.7 \\
\hline Race of respondent & Chinese & 16 & 15.0 \\
& Malay & $\mathbf{3 8}$ & $\mathbf{3 5 . 5}$ \\
& Indian & 28 & 26.2 \\
\hline
\end{tabular}




\begin{tabular}{|l|l|l|l|}
\hline Mood of work & Full time & 42 & 39.3 \\
& Part time & $\mathbf{6 5}$ & $\mathbf{6 0 . 7}$ \\
\hline Working experience & $\mathbf{7}$ months to 1 year & $\mathbf{7 7}$ & 17.8 \\
& 2 to 3 years & 11 & $\mathbf{7 2 . 0}$ \\
\hline Working per day & $\mathbf{5}$ to 10 hours & $\mathbf{6 6}$ & 10.3 \\
\hline & 11 to 15 hours & 41 & $\mathbf{6 1 . 7}$ \\
\hline
\end{tabular}

\section{RESULTS AND DISCUSSION}

The objective for this study was to identify the relationship between co-worker incivility and deviant behaviour with the moderating role of emotional labour among the frontline employees working in casual dining restaurants located in the Klang Valley. This thus required the use of Pearson Product Moment Correlation Coefficients to examine the relationship between variables. Findings of this analysis had determined whether the study's hypotheses were accepted or rejected. According to Cohen (1988), guidelines on the Pearson Correlation value (r) would enable the researcher to explain the strength and direction of association for the study's variables, subsequently leading the researcher to have a better view and understanding on the correlations involved. The interpretation of the correlation is as guided in Table 1.2.

Table 1.2: Interpretation of Correlation Coefficient (Cohen, 1988)

\begin{tabular}{|l|l|}
\hline $\begin{array}{l}\text { Degree } \\
\text { Correlation }\end{array}$ & of \\
\hline Small & $\begin{array}{l}-0.10 \text { to }-0.291 \text { and }+0.101 \text { to } \\
+0.29\end{array}$ \\
\hline Medium & $\begin{array}{l}-0.30 \text { to }-0.491 \text { and }+0.301 \text { to } \\
+0.49\end{array}$ \\
\hline Large & -0.50 to -1.001 and +0.501 to \\
& +1.00 \\
\hline
\end{tabular}

Table 1.3: the correlation between co-worker incivility and workplace deviant behaviour

\section{Correlations}

\begin{tabular}{|l|l|l|l|}
\hline \multicolumn{2}{|c|}{} & $\begin{array}{l}\text { Co-worker } \\
\text { Incivility }\end{array}$ & $\begin{array}{l}\text { Deviant } \\
\text { Behaviour }\end{array}$ \\
\hline Co-worker & $\begin{array}{l}\text { Pearson } \\
\text { Correlation }\end{array}$ & 1 & $.280^{* *}$ \\
\hline
\end{tabular}

Incivility

\begin{tabular}{|l} 
Sig. (2-tailed) \\
$\mathrm{N}$
\end{tabular}

107

**. Correlation is significant at the 0.01 level (2-tailed).

Table 1.3 depicts the findings on the correlation between coworker incivility and workplace deviant behaviour among the respondents in this study. The result points out that there was a significant moderate positive relationship between co-worker incivility and deviant behaviour with the correlation coefficient $(r=.280, p<.01)$. The result indicates that the coworker incivility has higher influence over employee workplace deviant behaviour. Therefore, research hypothesis was answered and supported.

\section{Effect of Emotional Labour Moderating the Relationship between Co-worker Incivility and Deviant Behaviour}

Table below shows the findings of the hierarchical regression analysis, investigating the effect of emotional labour as the moderating variable on the relationship between co-worker incivility and deviant behaviour. Model 1 explains 46.2 per cent of the variance, while Model 2 explains 49.6 per cent of the variance. Meanwhile, Model 3 explains 52.0 per cent of the variance with a 2.4 per cent increment in the total variance explained (see Table1.4). It was also found that there was a significant influence of emotional labour on the relationship between co-worker incivility and deviant behaviour $(\beta=.806$, $\mathrm{p}<.05)$. In addition, the interaction between frontline employees' emotional labour and deviant behaviour did strengthen the relationship between co-worker incivility and deviant behaviour $(\beta=.350, p>.05)$. The beta-value suggested that emotional labour has a unique contribution towards the relationship between co-worker incivility and deviant behaviour. High co-worker incivility also gives rise to high adaptation of emotional labour. Thus, the hypothesis was supported as there was a moderating effect of emotional labour on the relationship between co-worker incivility and deviant behaviour. 
Hierarchical Regressions between emotional labour, coworker incivility, and deviant behaviour is shown below:

\begin{tabular}{|c|c|c|c|}
\hline Variables & Model 1 & Model 2 & Model 3 \\
\hline \multicolumn{4}{|l|}{ Independent variable } \\
\hline Co-worker incivility & .261 & .247 & .306 \\
\hline \multicolumn{4}{|l|}{ Moderator } \\
\hline Emotional labour & & .200 & $.806^{*}$ \\
\hline \multicolumn{4}{|l|}{ Interaction Term } \\
\hline $\begin{array}{l}\text { Co-worker incivility* } \\
\text { Emotional labour }\end{array}$ & & & .350 \\
\hline R Square & .462 & .496 & .520 \\
\hline R Square Change & .462 & .034 & .024 \\
\hline F Change & 53.039 & 25.039 & 3.007 \\
\hline Sig. of F Change & .000 & .000 & .000 \\
\hline $\mathbf{F}$ & 53.039 & 51.985 & 30.291 \\
\hline Sig. & .000 & .000 & .000 \\
\hline Durbin Watson & & & 1.900 \\
\hline
\end{tabular}

\section{"significant with the \\ p-value $<.05$ Table 3}

Figure illustrates the moderating influence of emotional labour on the relationship between co-worker incivility and deviant behaviour. The graph shows that there are two different lines which are low emotional labour and high emotional labour. The results indicate that frontline employees with a high level of emotional labour possessing a high level of co-worker incivility were high performers of deviant behaviour. The second line represents frontline employees with a low level of emotional labour, possessing a low level of co-worker incivility thus showed low performance of deviant behaviour.

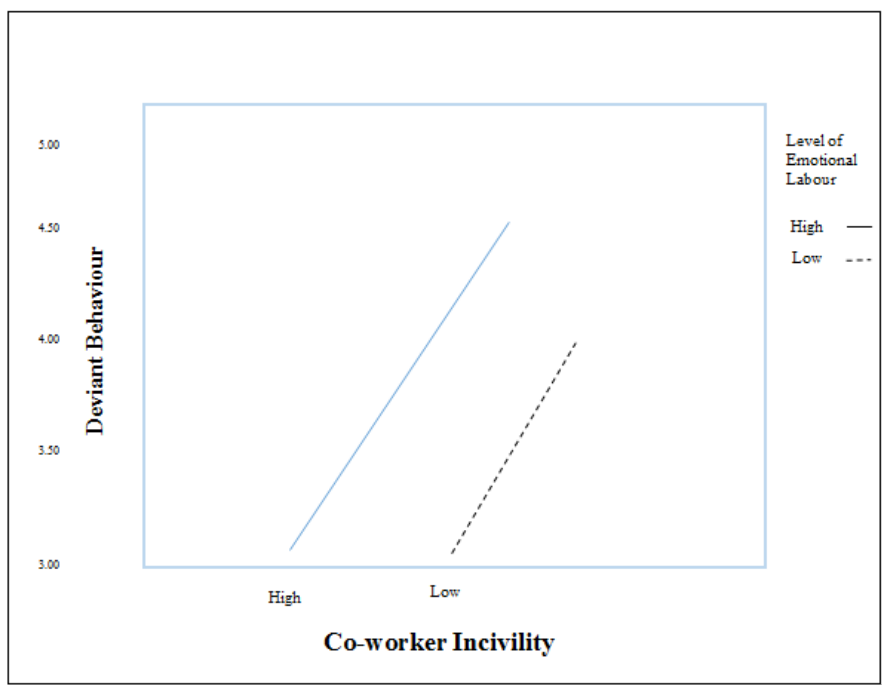

Figure 1: Illustration of Moderating Influence of Emotional Labour (Co-worker Incivility and Deviant Behaviour)

This study was conducted in casual dining restaurants in IOI Mall Putra Jaya in the Klang Valley where frontline employees had shown significant positive relation with deviant behaviour, as a response to incivility that they faced in their daily work life. Moreover, the researcher had identified acts of incivility which can lead to a spiral as well as leading to more intense forms of deviance such as violence and physiological disorder (Kim \& Qu,2019).

In fact, previous researchers added that incivility can lead to loss of productivity, reduction of voluntary efforts, retaliation towards the instigator, and turnover (Anjum \& Ming, 2018). Past study conducted by Smith and Morin, (2018) also indicated incivility received from work environment leads employee to engage in antisocial attitude that comes with financial obligation for the company. Thus, co-worker incivility is considered as one of the important triggering factors that promotes employees' negative attitude (Keller \& Yule, 2020). This research provide and evidence that Coworker incivility is prevailing in casual dining restaurants and there is lack of tanning facilities for front line employees. Therefor deviant behaviour is being hard to control by the concern authority. Drastic measures must be taken to control deviant behaviour

\section{CONCLUSION}

Deviant behaviour is like a virus in our society that is spreading rapidly and infecting our work culture. This study specifically targeted frontline employees working in casual dining restaurants (IOI Mall Putra Jaya) located in the Klang Valley. Based on the result analysis of this study, co-worker incivility was found to have influence over the frontline employees to performance towards deviance with the effect of emotional labour.

The researchers recognised some limitations throughout this study. First, the 
sample was limited to the (IOI Mall Putra Jaya) Klang Valley only. Therefore, it does not represent the whole picture of casual dining employees in Malaysia. It is recommended to expand the study in Peninsular Malaysia in order to get the real picture of the study. Furthermore, in future, it is recommended to apply probability sampling for generalisation in the context of Malaysian food and beverage services can be made. Different population can also be considered for future researches since adding up a moderating variable might show some different results or give the study a different view.

\section{Reference}

[1]. Aanonsen, T. M. (2020). Promoting a Culture of Respect in Healthcare Workforce (Doctoral dissertation, The College of St. Scholastica).

[2]. Abubakar, A. M., Megeirhi, H. A., \& Shneikat, B. (2018). Tolerance for workplace incivility, employee cynicism and job search behavior. The Service Industries Journal, 38(9-10), 629-643.

[3]. Anjum, A., Ming, X., Siddiqi, A. F., \& Rasool, S. F. (2018). An empirical study analyzing job productivity in toxic workplace environments. International journal of environmental research and public health, 15(5), 1035.

[4]. Agnew, R., \& Brezina, T. (2019). General strain theory. In Handbook on crime and deviance (pp. 145-160). Springer, Cham.

[5]. Anglim, J., Sojo, V., Ashford, L. J., Newman, A., \& Marty, A. (2019). Predicting employee attitudes to workplace diversity from personality, values, and cognitive ability. Journal of Research in Personality, 83, 103865.

[6]. Anthonia, A. A., \& Olalekan, A. J. (2018). Knowledge of banking services among frontline personnel and quality of service delivery in the Nigerian commercial bank. Journal of Business and Retail Management Research, 12(3).

[7]. Agnew, R., \& Brezina, T. (2019). General strain theory. In Handbook on crime and deviance (pp. 145-160). Springer, Cham.

[8]. Aryati, A. S., Sudiro, A., Hadiwidjaja, D., \& Noermijati, N. (2018). The influence of ethical leadership to deviant workplace behavior mediated by ethical climate and organizational commitment. International Journal of Law and Management.

[9]. Aljawarneh, N. M. S., \& Atan, T. (2018). Linking tolerance to workplace incivility, service innovative, knowledge hiding, and job search behavior: The mediating role of employee cynicism. Negotiation and Conflict Management Research, 11(4), 298-320.
[10]. Bennett, R. J., Marasi, S., \& Locklear, L. (2018). Workplace deviance. In Oxford research encyclopedia of business and management.

[11]. Barbieri, N., Clipper, S. J., Narvey, C., Rude, A., Craig, J. M., \& Piquero, N. L. (2019). Assessing general strain theory and measures of victimization, 2002-2018. Aggression and violent behavior, 49, 101304.

[12]. Bendersky, C., \& Brockner, J. (2020). Mistreatment from peers can reduce the effects of respectful treatment from bosses, and respectful peers can offset mistreatment from bosses. Journal of Organizational Behavior, 41(8), 722-736.

[13]. Cho, M., Bonn, M. A., Giunipero, L., \& Divers, J. (2019). Restaurant purchasing skills and the impacts upon strategic purchasing and performance: The roles of supplier integration. International Journal of Hospitality Management, 78, 293-303.

[14]. Choi, H. M., Mohammad, A. A., \& Kim, W. G. (2019). Understanding hotel frontline employees' emotional intelligence, emotional labor, job stress, coping strategies and burnout. International Journal of Hospitality Management, 82, 199-208.

[15]. Choi, Y., \& Ha, J. (2018). Job satisfaction and work productivity: The role of conflict-management culture. Social Behavior and Personality: an international journal, 46(7), 1101-1110.

[16]. Daly, A., Carey, R. N., Darcey, E., Chih, H., lamontagne, A. D., Milner, A., \& Reid, A. (2018). Workplace psychosocial stressors experienced by migrant workers in Australia: A cross-sectional study. Plos one, 13(9), e0203998.

[17]. Demsky, C. A., Fritz, C., Hammer, L. B., \& Black, A. E. (2019). Workplace incivility and employee sleep: The role of rumination and recovery experiences. Journal of occupational health psychology, 24(2), 228.

[18]. Delgado, C., Roche, M., Fethney, J., \& Foster, K. (2020). Workplace resilience and emotional labour of Australian mental health nurses: Results of a national survey. International journal of mental health nursing, 29(1), 35-46.

[19]. Di Stefano, G., Scrima, F., \& Parry, E. (2019). The effect of organizational culture on deviant behaviors in the workplace. The International Journal of Human Resource Management, 30(17), 2482-2503.

[20]. Engen, M., \& Magnusson, P. (2018). Casting for service innovation: The roles of frontline employees. Creativity and Innovation Management, 27(3), 255-269.

[21]. Eissa, G., Lester, S. W., \& Gupta, R. (2019). Interpersonal deviance and abusive supervision: The mediating role of supervisor negative emotions and the 
moderating role of subordinate organizational citizenship behavior. Journal of Business Ethics, 118.

[22]. Garcia, P. R. J. M., Restubog, S. L. D., Lu, V. N., Amarnani, R. K., Wang, L., \& Capezio, A. (2019). Attributions of blame for customer mistreatment: Implications for employees' service performance and customers' negative word of mouth. Journal of Vocational Behavior, 110, 203-213.

[23]. Geldart, S., Langlois, L., Shannon, H. S., Cortina, L. M., Griffith, L., \& Haines, T. (2018). Workplace incivility, psychological distress, and the protective effect of co-worker support. International Journal of Workplace Health Management.

[24]. Gualtieri, L., Rauch, E., Rojas, R., Vidoni, R., \& Matt, D. T. (2018). Application of Axiomatic Design for the design of a safe collaborative human-robot assembly workplace. In MATEC Web of Conferences (Vol. 223, p. 01003). EDP Sciences.

[25]. Haider, S., Nisar, Q. A., Baig, F., \& Azeem, M. (2018). Dark Side of Leadership: Employees' Job Stress \& Deviant Behaviors in Pharmaceutical Industry. International Journal of Pharmaceutical Research \& Allied Sciences, 7(2).

[26]. Hochschild, A., Irwin, N., \& Ptashne, M. (1983). Repressor structure and the mechanism of positive control. Cell, 32(2), 319-325.

[27]. Hussein, A. S. (2018). Revisiting the importance of casual dining experience quality: An empirical study. International Journal of Quality and Service Sciences.

[28]. Hur, W. M., Moon, T. W., \& Choi, W. H. (2019). When are internal and external corporate social responsibility initiatives amplified? Employee engagement in corporate social responsibility initiatives on prosocial and proactive behaviors. Corporate Social Responsibility and Environmental Management, 26(4), 849-858.

[29].

[30]. Javed, B., Fatima, T., Yasin, R. M., Jahanzeb, S., \& Rawwas, M. Y. (2019). Impact of abusive supervision on deviant work behavior: The role of Islamic work ethic. Business Ethics: A European Review, 28(2), 221-233.

[31]. Jin, D., Kim, K., \& DiPietro, R. B. (2020). Workplace incivility in restaurants: Who's the real victim? Employee deviance and customer reciprocity. International Journal of Hospitality Management, 86, 102459.

[32]. Karatepe, O. M., Kim, T. T., \& Lee, G. (2019). Is political skill really an antidote in the workplace incivility-emotional exhaustion and outcome relationship in the hotel industry? Journal of Hospitality and Tourism Management, 40, 40-49.
[33]. Kim, H., \& Qu, H. (2019). Employees' burnout and emotional intelligence as mediator and moderator in the negative spiral of incivility. International Journal of Contemporary Hospitality Management.

[34]. Kim, J., Siennick, S. E., \& Hay, C. (2018). The impact of strain on self-control: A longitudinal study of Korean adolescents. Youth \& Society, 0044118 X18773593

[35]. Keller, S., Yule, S., Zagarese, V., \& Parker, S. H. (2020). Predictors and triggers of incivility within healthcare teams: a systematic review of the literature. BMJ Open, 10(6), e035471.

[36]. Lavee, E., \& Strier, R. (2018). Social workers' emotional labour with families in poverty: Neoliberal fatigue?. Child \& Family Social Work, 23(3), 504-512.

[37]. Liu, L., Miller, S. L., \& Visher, C. A. (2019). The strain of procedural injustice in parole among former prisoners: A test with a mixed-gender sample. Justice Quarterly, 1-25.

[38]. Loh, J. M., \& Loi, N. (2018). Tit for tat: Burnout as a mediator between workplace incivility and instigated workplace incivility. Asia-Pacific Journal of Business Administration.

[39]. Lugosi, P. (2019). Deviance, deviant behaviour and hospitality management: Sources, forms and drivers. Tourism Management, 74, 81-98.

[40]. Lin, S., Yu, C., Chen, J., Zhang, W., Cao, L., \& Liu, L. (2020). Predicting adolescent aggressive behavior from community violence exposure, deviant peer affiliation and school engagement: A one-year longitudinal study. Children and youth services review, 111, 104840 .

[41]. Mendonca, A., D’Cruz, P., \& Noronha, E. (2018). Beauty service workers' encounters with abusive customers: Furthering the concept of external bullying at work. In Indian Perspectives on Workplace Bullying (pp. 205-235). Springer, Singapore.

[42]. Morgan, W. B., Perry, S. J., \& Wang, Y. (2018). The angry implications of work-to-family conflict: Examining effects of leadership on an emotionbased model of deviance. Journal of Vocational Behavior, 108, 13-27.

[43]. McKenna, N. C., Golladay, K. A., \& Holtfreter, K. (2020). Integrating General Strain Theory and Trauma-Informed Principles into the Study of Older Adult Victimization. Journal of Trauma \& Dissociation, 21(2), 187-200.

[44]. Miranda, M., \& Godwin, M. L. (2018). Emotional Labor Beyond the Frontlines: Work Settings, Interactions, and Coping Strategies. Administrative Theory \& Praxis, 40(4), 320-341. 
[45]. Nelson, J., Klumparendt, A., Doebler, P., \& Ehring, T. (2018). Everyday emotional dynamics in major depression. Emotion.

[46]. Nugroho, A., Oktavio, A., \& Kartika, E. W. (2019). Salesperson deviant behavior in Indonesian restaurant service attendants.

[47]. Nguyen, N., \& Stinglhamber, F. (2020). Workplace mistreatment and emotional labor: A latent profile analysis. Motivation and Emotion, 44(3), 474-490.

[48]. Olson, K., Sinsky, C., Rinne, S. T., Long, T., Vender, R., Mukherjee, S., \& Linzer, M. (2019). Cross- sectional survey of workplace stressors associated with physician burnout measured by the Mini- Z and the Maslach Burnout Inventory. Stress and Health, 35(2), 157-175.

[49]. Peterson, C., Stone, D. M., Marsh, S. M., Schumacher, P. K., Tiesman, H. M., McIntosh, W. L., \& Luo, F. (2018). Suicide rates by major occupational group-17 states, 2012 and 2015. Morbidity and Mortality Weekly Report, 67(45), 1253.

[50]. Peck, J. H., Childs, K. K., Jennings, W. G., \& Brady, C. M. (2018). General strain theory, depression, and substance use: Results from a nationally representative, longitudinal sample of White, African-American, and Hispanic adolescents and young adults. Journal of Child \& Adolescent Substance Abuse, 27(1), 11-28.

[51]. Portoghese, I., Leiter, M. P., Maslach, C., Galletta, M., Porru, F., D’Aloja, E.,\& Campagna, M. (2018). Measuring burnout among university students: factorial validity, invariance, and latent profiles of the Italian version of the Maslach Burnout Inventory Student Survey (MBI-SS). Frontiers in psychology, 9, 2105.

[52]. Radu-Lefebvre, M., \& Randerson, K. (2020). Successfully navigating the paradox of control and autonomy in succession: The role of managing ambivalent emotions. International Small Business Journal, 38(3), 184-210.

[53]. Roter, A. B. (2018). The dark side of the workplace: managing incivility. Routledge.

[54]. Roberts, J. A., \& David, M. E. (2020). Boss phubbing, trust, job satisfaction and employee performance. Personality and Individual Differences, 155, 109702.

[55]. Rasool, S. F., Maqbool, R., Samma, M., Zhao, Y., \& Anjum, A. (2019). Positioning depression as a critical factor in creating a toxic workplace environment for diminishing worker productivity. Sustainability, 11(9), 2589.

[56]. Saad, M., AbuKhalifeh, A. N., Slamat, S. S., \& TengkuYacob, T. N. F. F. (2020). Assessing the Use of Linear Regression Analysis in Examining
Service Quality and Customer Satisfaction Relationship in Premium Casual Restaurants (PCR) in Subang Jaya (Klang Valley) Malaysia. Review of Integrative Business and Economics Research, 9, 369-379.

[57]. Smith, J. G., Morin, K. H., \& Lake, E. T. (2018). Association of the nurse work environment with nurse incivility in hospitals. Journal of nursing management, 26(2), 219-226.

[58]. Schnall, P. L., Dobson, M., Rosskam, E., \& Elling, R. H. (2018). Unhealthy work: Causes, consequences, cures. Routledge.

[59]. Shoaib, S., \& Baruch, Y. (2019). Deviant behavior in a moderated-mediation framework of incentives, organizational justice perception, and reward expectancy. Journal of business ethics, 157(3), 617633.

[60]. Mr. B. Naga Rajesh. (2019). Effective Morphological Transformation and Sub-pixel Classification of Clustered Images. International Journal of New Practices in Management and $\begin{array}{lllll}\text { Engineering, } & 8(01), & 08 & - & 14\end{array}$ https://doi.org/10.17762/ijnpme.v8i01.74

[61]. Dr. M. Varadharaj. (2019). Density Based Traffic Control System with Smart Sensing Of Emergency Vehicles. International Journal of New Practices in Management and Engineering, 8(02), 01 - 07. https://doi.org/10.17762/ijnpme.v8i02.75

[62]. Dr. S.A. Sivakumar. (2019). Hybrid Design and RF Planning for $4 \mathrm{G}$ networks using Cell Prioritization Scheme. International Journal of New Practices in Management and Engineering, 8(02), 08 - 15. https://doi.org/10.17762/ijnpme.v8i02.76

[63]. Mr. R. Senthil Ganesh. (2019). Watermark Decoding Technique using Machine Learning for Intellectual Property Protection . International Journal of New Practices in Management and $\begin{array}{lllll}\text { Engineering, } & 8(03), & 01 & - & 09 .\end{array}$ https://doi.org/10.17762/ijnpme.v8i03.77

[64]. Mr. Dharmesh Dhabliya, Dr.S.A.Sivakumar. (2019). Analysis and Design of Universal Shift Register Using Pulsed Latches . International Journal of New Practices in Management and Engineering, $\quad 8(03), \quad 10 \quad-\quad 16$. https://doi.org/10.17762/ijnpme.v8i03.78

[65]. Sguera, F., Bagozzi, R. P., Huy, Q. N., Boss, R. W., $\&$ Boss, D. S. (2016). Curtailing the harmful effects of workplace incivility: The role of structural demands and organization-provided resources. Journal of Vocational Behavior, 95, 115-127.

[66]. Taylor, E. A., Hardin, R., Welch, N., \& Smith, A. B. (2018). Incivility in the workplace: The experiences of female sport management faculty in higher 
education.

[67]. Tuzun, I. K., \& Kalemci, R. A. (2018). Workplace deviance and human resource management relations: A case study of Turkish hotel employees. Journal of Human Resources in Hospitality \& Tourism, 17(2), 137-153.

[68]. Tuzun, I. K., \& Kalemci, R. A. (2018). Workplace deviance and human resource management relations: A case study of Turkish hotel employees. Journal of Human Resources in Hospitality \& Tourism, 17(2), 137-153.

[69]. Viotti, S., Converso, D., Hamblin, L. E., Guidetti, G., \& Arnetz, J. E. (2018). Organisational efficiency and co- worker incivility: A cross- national study of nurses in the USA and Italy. Journal of nursing management, 26(5), 597 604.

[70]. Winter, K., Morrison, F., Cree, V., Ruch, G., Hadfield, M., \& Hallett, S. (2019). Emotional labour in social workers' encounters with children and their families. The British Journal of Social Work, 49(1), 217-233.

[71]. Wirtz, J., Patterson, P. G., Kunz, W. H., Gruber, T., Lu, V. N., Paluch, S., \& Martins, A. (2018). Brave new world: service robots in the frontline. Journal of Service Management.

[72]. Wolf, L. A., Perhats, C., Clark, P. R., Moon, M. D., \& Zavotsky, K. E. (2018). Workplace bullying in emergency nursing: Development of a grounded theory using situational analysis. International emergency nursing, 39, 33-39.

[73]. Wu, X., Li, J., Liu, G., Liu, Y., Cao, J., \& Jia, Z. (2018). The effects of emotional labor and competency on job satisfaction in nurses of China: A nationwide cross-sectional survey. International journal of nursing sciences, 5(4), 383-389.

[74]. Xu, S. T., Cao, Z. C., \& Huo, Y. (2020). Antecedents and outcomes of emotional labour in hospitality and tourism: A meta-analysis. Tourism Management, 79, 104099.

[75]. Yildız, M., \& Solakoglu, Ö. (2019). Strain, negative emotions, and suicidal behaviors among adolescents: testing general strain theory. Youth \& Society, 51(5), 638-658.

[76]. Yusof, Y. L. M., Jusoh, W. J. W., \& Maulan, S. (2020). Perceived quality association as determinant to re-patronise Shariah-compliant brand restaurants. Journal of Islamic Marketing.

[77]. Yuniasanti, R., Abas, N. A. H., \& Hamzah, H. (2019). Experienced Workplace Incivility: Developing Emotional Exhaustion as a Mediator and Its Consequences Among Millennial Employees. Jurnal psikologi malaysia, 33(1).
[78]. Zheng, M. X., \& van Dijke, M. (2020). Expressing forgiveness after interpersonal mistreatment: Power and status of forgivers influence transgressors' relationship restoration efforts. Journal of Organizational Behavior, 41(8), 782-796.

[79]. Zhu, J. N., Lam, L. W., \& Lai, J. Y. (2019). Returning good for evil: A study of customer incivility and extra-role customer service. International Journal of Hospitality Management, 81, 65-72. 